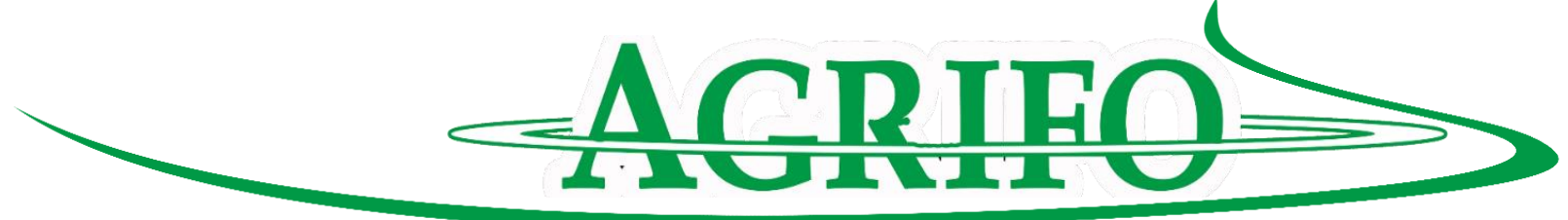

\title{
PERAN PEREMPUAN DALAM KETERSEDIAAN PANGAN RUMAHTANGGA (STUDI KASUS PADA MASYARAKAT PETANI PADI DI GAMPONG BLANG PALA, KECAMATAN BANDA BARO, KABUPATEN ACEH UTARA, PROVINSI ACEH)
}

\author{
Nurasih Shamadiyah ${ }^{1}$, Pangeran Putra Perkasa Alam Nasution² \\ Corresponding Author : nurasih@unimal.ac.id
}

\begin{abstract}
The rice farmers community as producers of staple food for food needs of the community is considered to have certainty in food security. Not only they have to produce food commodities, but they are also responsible for the availability of food for all their families and the community. This study aims to describe the division of roles between women and men in agricultural and non-farm activities (on farm and off farm) in order to fill household food security in rice farming communities in Blang Pala Village, Banda Baro District, Aceh Utara Regency, Aceh Province. The study was conducted by in-depth interviews with ethno-science as the approach. The informants are determined based on several conditions, such as full of involvement in agricultural and non-agricultural activities, informants who are directly involved in the cultural atmosphere, and have different social and cultural backgrounds with researchers. Informants in this study were divided into female farmers and male farmers. The results of the study show that women have a real and very important contribution to food security of their family. Women have a very important role in the effort to provide food at the household level because women are fully involved both in agricultural activities and outside agricultural activities. Although basically those who make a livelihood are not the main task of women, but when it comes to providing food, it becomes a duty of women in their families.
\end{abstract}

Keywords: roles of women, farmers, food security, food availability

\section{PENDAHULUAN}

Pembangunan pertanian bertujuan untuk meningkatkan pendapatan dan taraf hidup petani, pertumbuhan kesempatan kerja dan berusaha, meningkatkan gizi dan ketahanan pangan rumahtangga, dan mengentaskan kemiskinan di perdesaan. Semua ini berkaitan erat dengan peran, tugas, dan fungsi perempuan di perdesaan. Meskipun begitu, sektor pertanian dan lapangan kerja primer tidak terlalu banyak menyerap tenaga kerja perempuan. Berpedoman kepada pendapatan rumahtangga yang dapat dihasilkan oleh suami maupun istri (pola nafkah ganda), perempuan memiliki peluang kerja yang dapat menghasilkan pendapatan bagi rumahtangganya, sebagai upaya mengurangi kemiskinan di perdesaan.

Peran dan kedudukan merupakan dua aspek penting dalam hubungan sosial bermasyarakat. Peran merupakan perilaku individu yang penting bagi struktur sosial, yang akhirnya akan memberikan fasilitas tertentu sesuai dengan peranan tersebut. Peran (role) merupakan aspek dinamis dari status, bilamana seseorang telah melakukan kewajiban sesuai dengan statusnya, maka ia telah berperan. Status sering

\footnotetext{
${ }^{1}$ Program Studi Agribisnis Fakultas Pertanian Universitas Malikussaleh

2 Program Studi Antropologi Fakultas Ilmu Sosial dan Politik Universitas Malikussaleh
} 
diakronimkan menjadi kedudukan, yang mengindikasikan posisi seseorang secara sosial di masyarakat. Dengan kata lain, kedudukan memberikan seseorang dengan suatu peran sebagai pola interaksi anggota masyarakat dalam bersosialisasi (Holy, 1996).

Berbagai pendekatan dapat digunakan untuk mengkaji peran dan kedudukan/status sosial perempuan tani, namun pada dasarnya bermula dari telaah the family structure (struktur keluarga) sebagai unit terkecil dalam sistem masyarakat (society) dan kekerabatan (kinship). Sajogyo (1994) mengemukakan pentingnya memperhatikan lima substruktur berikut: (1) diferensiasi peranan, (2) alokasi ekonomi, (3) alokasi solidaritas, (4) alokasi kewibawaan/kekuasaan, dan (5) alokasi integrasi dan ekspresi. Seluruh substruktur tersebut berfungsi sebagai pendukung kelangsungan hidup sistem kekerabatan dalam rumahtangga maupun dalam bersosialisasi dan bermasyarakat.

Suatu kelompok masyarakat akan terjadi keseimbangan ketika peran dan kedudukan berjalan secara seimbang. Apabila semua orang mampu berperan sesuai peranannya, maka belum tentu masyarakat memberi peluang yang seimbang pula. Bahkan seringkali ditemukan masyarakat "terpaksa" membatasi peluang-peluang tersebut, seperti halnya yang terjadi pada kaum perempuan tani di perdesaan, yang semuanya berkaitan dengan kemampuan (potensi) yang melekat pada diri mereka. Potensi merupakan kemampuan sebagai daya dukung yang dimiliki secara khas oleh masing-masing individu, yang membuatnya mampu berperan sesuai atau tidak sesuai dengan kedudukannya.

Perempuan berperan penting dalam berbagai bidang. Kita dapat ambil contoh, peran kaum hawa dalam ketahanan pangan, gizi dan kesehatan keluarga. Di dalam bidang ini, seorang perempuan mengambil keputusan, misalnya memilih bahan pangan, mengolahnya secara sehat, dan memilih kebutuhan rumah tangga yang ramah lingkungan. Oleh sebab itu, pengetahuan tentang bahan pangan sehat dan memenuhi kebutuhan gizi, cara pengolahannya dan kebutuhan rumahtangga yang ramah lingkungan menjadi penting untuk dimiliki setiap perempuan Indonesia. Potensi perempuan dalam pembangunan pertanian sangat strategis. Bahkan kontribusi pendapatan perempuan di perdesaan dan pertanian terhadap pendapatan rumahtangga sangat besar. Dari 23 juta kepala keluarga petani di Indonesia, sebagian besar dari mereka adalah perempuan, istri atau ibu yang juga terlibat di sektor pertanian. Tetapi pada kenyataannya peran perempuan di sektor pertanian sering termarginalisasi akibat budaya patriarki yang berkembang di masyarakat yang menyebabkan terjadinya pembagian kerja secara gender di bidang pertanian, perbedaan curahan jam kerja dan tingkat upah dalam pertanian. Berkaitan dengan peran perempuan dalam bidang pertanian, mereka terlibat dalam kegiatan pertanian yang berat seperti mengolah sawah, maupun kegiatan pertanian yang ringan seperti mengolah pekarangan pertanian (Novia, 2015).

Ketahanan pangan tidak terlepas dari peran para petani perempuan. Perempuan terlibat dalam kegiatan produksi (on farm), pengolahan sampai distribusi pangan. Mereka bukan hanya menghasilkan pangan, tetapi juga menjadi penanggung jawab utama terhadap kebutuhan asupan gizi bagi seluruh anggota keluarganya. Dari berbagai hasil penelitian menunjukkan bahwa kaum perempuan merupakan 
faktor penentu dalam ketahanan pangan bagi keluarganya, mulai dari proses produksi di lahan pertanian, pemasaran sampai menyediakan pangan di meja makan serta bertanggung jawab dalam pemenuhan gizi keluarga sehingga perempuan memiliki kontribusi yang sangat penting dalam ketahanan pangan keluarga. Perempuan mempunyai peran yang sangat penting dalam upaya konsumsi bahan pangan pada tingkat rumahtangganya mengingat bahwa di tangan perempuan atau seorang ibulah bahan pangan direncanakan, diolah dan dipersiapkan sebagai hindangan bagi keluarganya. Besar kecilnya anggaran dalam merencanakan, mengolah, mempersiapkan dan menghidangkan bahan pangan juga menjadi dasar bagi seorang perempuan (ibu rumahtangga) dalam upaya memperbaiki kualitas pangan yang dikonsumsi oleh keluarganya (Novia, 2015).

\section{METODE PENELITIAN}

Penelitian ini merupakan suatu penelitian sosial-budaya dengan etnosains sebagai pendekatannya. Data yang diperoleh dan digunakan dalam penelitian ini adalah jenis data kualitatif, berupa pernyataan-pernyataan mengenai isi, sifat, ciri, dan keadaan dari sesuatu atau gejala, atau pernyataan mengenai berbagai hubungan antara sesuatu dengan sesuatu yang lain. Data yang dihimpun sesuai fokus penelitian berupa kata-kata, tindakan, situasi, dokumentasi dan peristiwa yang diobservasi. Pengumpulan data/informasi ini, peneliti sekaligus sebagai instrumen yang dilakukan dengan dokumentasi dan kegiatan wawancara (indepth interview). Oleh karenanya, peneliti akan mencatat, serta menggunakan dukungan alat perekam, dan mengamati perilaku orang yang diwawancarai. Penelitian dilaksanakan di Desa (Gampong) Blang
Pala, Kecamatan Banda Baro, Kabupaten Aceh Utara, Provinsi Aceh.

Penentuan informan dalam penelitian ini didasarkan atas ciri-ciri, sifat maupun karakteristik tertentu yang merupakan representasi tineliti. Pemilihan informan ditentukan sesuai konteks informasi yang hendak digali. Sebagaimana dikemukakan oleh Spradley (2007), bahwa para informan ditentukan berdasarkan beberapa syarat minimal: enkulturasi penuh, keterlibatan langsung informan dengan suasana budayanya, latar belakang budaya yang berbeda dengan peneliti, ketercukupan waktu, dan non analitik.

Kelompok informan dalam penelitian ini dibedakan menjadi petani perempuan dan petani laki-laki. Data yang dipergunakan dalam penelitian ini, agar diperoleh hasil penelitian yang valid akurat dan dapat dipertanggungjawabkan hasilnya, maka data penelitian dibagi menjadi 2 (dua) bagian yaitu data primer dan data sekunder. Teknik pengumpulan data menggunakan observasi, wawancara, dan dokumentasi. Analisis Data atau Pengolahan Data adalah bentuk analisis yang lebih rinci dan mendalam yang membahas suatu tema atau pokok permasalahan. Di mana dalam analisis ini, fokus penelitian maupun pembahasan kendati diarahkan pada bidang atau aspek tertentu. Pelaksanaan analisis data kualitatif bertujuan pada penggalian makna, penggambaran, penjelasan dan penempatan data pada konteksnya masing-masing. Uraian data jenis ini berupa kalimat-kalimat, bukan angka-angka. Berangkat dari pemikiran di atas, dan terkait dengan fokus kajian dalam penelitian ini, maka, dibutuhkan suatu pendekatan yang relevan. Salah satu pendekatan yang dianggap tepat untuk digunakan dalam kajian ini adalah pendekatan 'etnosains', sebagai salah 
satu perspektif teoretik dalam antropologi.

Tujuan dan metode dari pendekatan etnosains ini adalah untuk melukiskan realitas kehidupan menurut sudut pandang masyarakat (tineliti). Pendekatan ini berangkat dari asumsi utama mengenai pengalaman efektif atau (effective experiences) bersifat kultural karena pengalaman hidup yang sama, dan umumnya dapat 'dilihat' atau 'dipahami' (perceived) secara berlainan oleh masyarakat yang berbeda latar belakang kebudayaannya.

\section{HASIL DAN PEMBAHASAN}

Blang Pala awalnya merupakan bagian dari Kecematan Dewantara memisahkan diri dan bergabung dengan 43 Gampong lainnya membentuk Kecamatan Nisam. Namun setelah hampir 3 dekade dibawah wilayah Birokratif Nisam Gampong Blang Pala kemudian bersama dengan 9 Gampong lainnya dikawasan mukim Banda Baro dan Lhok Weeng memisahkan diri dan membentuk Kecematan Banda Baro sampai sekarang. Rata-rata penduduk Gampong Blang Pala memiliki profesi sebagai petani dan profesi lainnya yang tidak menentu. Sebagian besarnya mengharapkan pendapatannya di sektor pertanian, perkebunan dan perikanan. Masih sangat sedikit yang memilki pendapatan selain 3 jenis pekerjaan tersebut. Namun, seiring keluarnya UU Desa No. 6 Tahun 2014 dengan bantuan anggaran yang sangat besar bagi desadesa di seluruh Indonesia, Gampong Blang Pala merasa optimis jika dana tersebut nantinya dapat digunakan untuk memperkuat pondasi ekonomi Gampong dan warga, khususnya untuk sektorsektor terapan dalam hal budidaya pertanian, perkebuanan dan perikanan di Gampong Blang Pala.
Gampong Blang Pala memiliki beberapa potensi sumber daya alam yang dimanfaatkan untuk kebutuhan ekonomi, baik yang berasal dari pemanfaatan lahan untuk pertanian. Dengan luas wilayah keseluruhan desa mencapai 1298,5 Ha, masing-masing terbagi untuk wilayah permukiman, sawah dan kebun. Adapun sumber daya alam yang dimiliki oleh Gampong Blang Pala, diantaranya adalah:

1. Pertanian (padi, cabai, tomat)

2. Perkebunan (kelapa, coklat, pinang, ubi dll)

3. Peternakan (sapi, kambing, domba, ayam, kerbau dan bebek)

4. Perikanan (lel, mujahir dll)

Gampong Blang Pala merupakan kawasan pedesaan yang bersifat agraris, dengan mata pencaharian sebagai besar penduduknya adalah bercocok tanam, terutama bertani dan berkebun. Sedangkan pencaharian lainnya adalah dari pemanfaatan hasil olahan pertanian dan perkebunan. Sektor pertanian menjadi sumber mata pencaharian bagi masyarakat Gampong Blang Pala. Bertani adalah pekerjaan yang mulia selain untuk kehidupannya sendiri juga penting bagi kelestarian alam dan mahkluk lainnya. Dengan adanya kegiatan di sektor pertanian, masyarakat memperoleh pangan yang merupakan kebutuhan pokok untuk keberlanjutan kehidupannya. Kearifan lokal merupakan bagian kebudayaan sehingga kebudayaan ini menjadi suatu kebiasaan yang dapat dipelajari dalam suatu masyarakat. Ketika kebudayaan itu masih bermanfaat bagi masyarakat maka kebudayaan tersebut akan terus dipakai (Shamadiyah, Praza, \& Martina, 2018). Kegiatan bertani padi di Gampong Blang Pala meliputi rangkaian beberapa aktivitas sebagai berikut: 
Tabel 1. Kalender Pertanian di Gampong Blang Pala

\begin{tabular}{l} 
Kegiatan Utama di Sawah \\
\hline Duek Rapat (JUNI) \\
Setelah turun lapangan untuk mengecek \\
irigasi dan lain-lain yang dilakukan oleh \\
Geujrun (dari Kecamatan), selanjutnya \\
diatur pertemuan untuk Duek Rapat \\
membahas perbaikan irigasi yang rusak \\
atau sumbat, \\
kapan tanggal atau bulan pasti untuk turun \\
ke sawah. Agar Geuchik bisa \\
mengumumkan ke masyarakat, karena \\
setiap irigasi punya haknya masing- \\
masing. Sampai ada keputusan untuk \\
dilepaskan air irigasi. Adapun sebelum \\
irigasi dilepas Geuchik membagi tugas \\
untuk gotong royong membersihkan \\
irigasi ini dengan masyarakat. Berapa \\
jumlah pembagian meter jarak irigasi yang \\
dibersihkan per Gampong merupakan \\
keputusan pihak kecamatan.
\end{tabular}

Kegiatan Upacara Adat

Pada saat Duek Rapat berlangsung

biasanya disuguhkan makanan dan

minuman seadanya. Yang disiapkan pihak

kecamatan. Duek Rapat dihadiri oleh

Geuchik, Geujrun dan pihak kecamatan yang bertugas dibidang ini.
Gotong Royong (AWAL JULI)

Gotong royong irigasi di sekitar sawah masing-masing yang sudah ditetapkan.
Konsumsi ditanggung dengan uang denda yang dibayarkan oleh masyarakat yang tidak datang ikut gotong royong Rp 20.000,-/ orang. Cara membaginya dengan masyarakat biasanya ditargetkan untuk uang minum Rp. 5000,-/orang, Jika dari uang denda tidak cukup maka ditambah uang pribadi oleh Geuchik.

\section{Persiapan Turun Sawah (JULI)}

Setelah semua proses pembersihan dan perbaikan selesai maka masyarakat siap untuk turun ke sawah.
Upacara Khanduri Blang yaitu kenduri turun sawah. Pelaksanaan uapacara sebelum turun ke sawah. Masyarakat melakukan musyawarah yang pesertanya diwakili oleh laki-laki yaitu kepala rumahtangga (Ayah) masing-masing keluarga atau anak laki-lakinya.

Pembahasan terkait dengan menu yang akan dihidangkan untuk Khanduri

Blang. Biasanya masyarakat menyiapkan seekor sapi atau seekor kambing dengan biaya yang dibebankan pada masyarakat sebanyak $\mathrm{Rp}$ 50.000./orang ataupun membawa bekal pribadi dari rumah yang nantinya akan saling tukar menukar bekal dalam acara Khanduri Blang. Upacara ini dilakukan di dekat sebuah Balai Gampong yang jaraknya tak 
jauh dari persawahan Gampong Blang Pala.

Setelah sepakat dengan rangkaian tersebut lalu ditentukan tanggal yang disepakati bersama.

\section{Bajak Sawah (AGUSTUS)}

Setelah Khanduri Blang masyarakat bebas kapan saja mau mulai menanam padi masing-masing tergantung semangat kerjanya, tetapi hanya sedikit yang bermalas-malasan, hampir seluruh masyarakat turun ke sawah bersamasama. Adapun sebelum turun menanam padi ada persiapan yang dilakukan seperti, pembajakan dengan menggunakan traktor dorong milik pribadi yang disewa masyarakat Gampong. Pembajak sawah juga menggunakan tenaga buruh tani yang dibayar atau menggunakan tenaga anggota keluarganya. Dalam waktu seminggu sampai dengan sepuluh hari biasanya seluruh sawah milik masyarakat Gampong Blang Pala selesai dibajak.

\section{Tempat Pembibitan dan Bibit} Khatimoh (AGUSTUS)

Padi direndam 1 hari dalam air kemudian diangkat dan dimasukkan dalam karung, diamkan selama 2 hari dan tunggu tunas padi muncul (Selimoh). Setelah itu siapkan tempat

pembibitan padi yang sudah muncul tunasnya untuk dimasukkan dalam sebagian sawah, lalu padi yang bertunas tersebut ditaburkan. Tunggu sampai 18 hari.

\section{Ceumacah dan Tak Ateung (AGUSTUS)}

Selagi masa tunggu bibit 18 hari, sawah harus disiapkan secara keseluruhan terlebih dahulu untuk penanaman bibitnya. Pertama, Ceumacah membersihkan rumput liar yang tumbuh di dalam sawah. Kedua, Tak Ateung membersihakn pinggiran sawah. Jika sawah tidak bersih atau berumput maka padi akan jadi rusak, banyak penyakit dan hama.

\begin{tabular}{lrlll}
$\begin{array}{l}\text { Beut Bijeh } \\
\text { (SEPTEMBER) }\end{array}$ & dan & Seumula & $\begin{array}{l}\text { Ada aturan dari pemerintah. } \\
\text { memberikan ruang untuk petani dapat }\end{array}$ \\
\hline
\end{tabular}


Beut bijeh adalah mencabut bibit padi yang sudah ditanam selama 18 hari. Adapun selanjutnya petani melakukan Seumula yaitu penanaman bibit padi pada poros yang sudah diukur menggunakan tali. Masyarakat meletakkan enam bibit selang saturuang. berjalan pada saat proses penyemprotan dan lain-lain. Adapun aturan ini juga dibuat agar sehat padi nya tumbuh melebar tidak kesempitan. Ukuran luas

ruang antar padi juga ditentukan oleh pemerintah kecamatan yaitu $20 \mathrm{~cm}$. Pada dasarnya ada juga aturan dalam meletakkan jumlah bibit yaitu dua bibit selang satu ruang. Hal ini bertujuan agar padi sehat dan sedikit hamanya, tetapi dalam pengerjaannya lebih melelahkan khususnya kaum perempuan yang bertanggung jawab dalam hal penanaman padi.

\section{Penyemprotan Abo (SEPTEMBER)}

Setelah penanaman padi selesai sore harinya dilakukan penyemprotan keong $(A b o)$ menggunakan racun khusus pembasmi hama keong yaitu bentan.

\section{Pemupukan Pertama (SEPTEMBER)}

Pemupukan pertama dilakukan lima hari setelah penanaman padi. Pupuk yang digunakan adalah pupuk urea yang dicampur dengan pupuk SP36. SP36 Berguna untuk melunakkan tanah, sedangkan pupuk urea untuk vitamin pada padi.

Hari kelima belas (SEPTEMBER)
15 hari setelah penananman, masyarakat
melakukan penyemprotan hama ulat. Racun yang digunakan adalah Prevaton yang dicampur dengan sygenta. Hal ini dilakukan karena banyak jenis ulat jadi harus ada 2

sampai 4 campuran racun.

Setelah 70 hari padi sudah mulai pembuahan kemudian pupuk yang dipakai harus segera diganti untuk penyemprotan perawatan pembuahan agar hasilnya banyak dan bagus.

Penyemprotan menggunakan pupuk boster dan menggunakan beberapa campuran pupuk lainnya untuk batang, daun dan isinya.
Selesai tugas pemupukan hari ke lima, petani bisa bersantai sampai lima belas hari penanaman padi.

Begitu seterusnya petani melakukan penyemprotan setiap lima belas hari sekali untuk hama ulat sampai dengan tujuh puluh hari sebelum padi berisi.

Khanduri 70 hari dilakukan untuk syukuran. Mengirim doa agar padinya bagus. Hasil panennya banyak. Kegiatan Khanduri ini dilaksanakan oleh seluruh masyarakat. Musyawarah kecil dilakukan oleh aparat Gampong. Nama upacara ini adalah menienem. Menienem memiliki menu yang khas yaitu Bu Teususop. Cara penyajiannya yaitu dengan nasi diletakkan dalam talam yang sudah dicampur semua lauk dan kuah sayur semuanya, setelah dicampur semua baru dibagikan pada seluruh masyarakat. Budaya ini sudah ada dari zaman dulu. Biasanya doa yang 


\section{Penyemprotan buah padi atau Tikui}

\section{(DESEMBER)}

15 hari kemudian tahap kedua penyemprotan buah padi. Tunggu genap 110 hari atau lebih sampai padi siap di panen.

\section{Keumeukoh atau panen (DESEMBER) Turun ke sawah untuk keumekoh sepenuhnya tugas perempuan dan termasuk menentukan tanggal untuk padi siap dipanen juga perempuan. Adapun setelah dipotong, jemur dan tunggu sampai padinya mengering 2- 3 jam dibawah sinar matahari. Padi yang sudah kering diangkat (nibay) dan dikumpulkan di suatu tempat kemudian hasil padi digiling menggunakan mesin perontok padi. Hasil panen atau padi dimasukkan dalam karung dan diangkut lalu dijual.}

Penjualan padi biasanya tidak semua dijual, tetapi 8-10 karung disimpan untuk persediaan pangan rumahtangga petani. Kegiatan jual padi dilakukan oleh laki-laki karena setiap karung yang berisi padi sangat berat. Tetapi tak jarang juga ada perempuan yang membantu sampai padi dibawa ke pengepul dan dijual. Pada saat proses penjualan padi selesai terkadang beberapa petani laki-laki yang tidak ikut petani perempuannya dalam proses penjuualan biasanya tidak langsung mengambil uangnya tetapi hanya mengambil fakturnya saja. Faktur lalu diberikan kepada istri. Istri akan mengambil uangnya kemudian membayar hutang obat untuk pengurusan padi. Sisanya disimpan dan digunakan untuk keperluan rumah tangga petani.

Pascapanen seluruh binatang peliharaan boleh dilepas ke dalam area sawah.

Pada musim pascapanen anak-anak turun ke sawah untuk bermain dan mencari kulat atau jamur jerami.

Petani perempuan di Gampong Blang Pala tidak menjual semua hasil panen sawah mereka. Sebagian disisihkan untuk kebutuhan pangan keluarganya. Rata-rata mereka menyisihkan rata-rata 10 karung beras berbagai ukuran mulai dari $10 \mathrm{Kg}, 15$ $\mathrm{Kg}, 16 \mathrm{Kg}, 25 \mathrm{Kg}$, bahkan sampai $60 \mathrm{Kg}$ untuk kebutuhan beberapa bulan ke depan. Hal ini telah menjadi kebiasaan mereka sejak mereka mulai menjadi petani dan berkeluarga. Jika hasil panen tidak sesuai dengan harapan, petani perempuan di Gampong Blang Pala memilih untuk tidak menjual hasil pertanian mereka ke pasar. Menurut mereka, kebutuhan pangan keluarga lebih penting. Selain menyisihkan hasil pertanian untuk kebutuhan keluarga, mayoritas informan juga mendapatkan bantuan beras miskin (Raskin) dari pemerintah sebanyak $4 \mathrm{Kg}$ per Kepala Keluarga. Petani perempuan di Gampong Blang Pala juga menanam berbagai jenis macam sayuran seperti kacang panjang, kangkung, bayam, cabai, dan lain-lain. Hal ini diperuntukkan jika tidak ada pendapatan atau kurangnya pendapatan dari hasil pertanian padi sawah, mereka masih tetap bisa makan dan menyediakan makanan bagi keluarganya. Tanaman sayuran ini ditanam di pekarangan rumah. 
Petani perempuan juga bertanggungjawab atas pemeliharaan ternak. Hewan yang diternakan antara lain ialah sapi, kambing, ayam, dan bebek. Mengapa perempuan yang memelihara dan menjaga hewan ternak, karena perempuan dianggap telaten dalam pemeliharaan seperti pemberian pakan dan membersihkan kandang. Petani laki-laki hanya bertugas menjual hasil ternak ke pasar jika diperlukan atau yang menyembelih hewan ternak tersebut untuk kebutuhan pangan keluarga. Hewan ternak disini menjadi tabungan bagi petani ketika ingin mendapatkan pendapatan lebih untuk kebutuhan tertentu dan sebagai jaminan ketika tidak memiliki pendapatan. Hewan ternak yang dimiliki petani di Gampong Blang Pala tergolong tidak banyak dan tidak diusahakan secara intensif, hanya untuk tabungan dan jaminan keuangan ketika tidak memiliki pendapatan atau kebutuhan mendadak. Mereka lebih memilih tabungan berbentuk hewan ternak daripada menabung uang secara modern di bank atau menabung secara konvensional dengan perhiasan. Tabungan dengan hewan ternak dianggap lebih memudahkan masyarakat petani untuk menjualnya dibandingkan dengan tabungan benda berharga.

Hewan ternak ini juga dapat dimanfaatkan ketika tidak tersedia lauk makanan karena tidak memiliki pendapatan. Selain dagingnya, hewan ternak seperti ayam dan bebek juga dimanfaatkan telurnya untuk kebutuhan pangan keluarga. Untuk lauk pangan nabati seperti tahu dan tempe, masyarakat petani membelinya di warung terdekat, pedagang sayur keliling, maupun membeli langsung ke pasar Simpang Elak atau Krueng Geukeuh. Bahan pangan yang dibeli adalah hasil pertanian atau perikanan yang tidak bisa mereka hasilkan sendiri seperti bawang merah, rempah-rempah, ikan, udang, wortel, kentang, dan lainlain. Biasanya para ibu ke pasar dua sampai 3 kali dalam seminggu. Bahkan ada juga yang hanya seminggu sekali karena semua kebutuhan pangan sudah tersedia di sekitar mereka.

Petani perempuan atau para ibu sangat berperan dalam ketersediaan pangan dalam keluarganya. Semua tugas yang berkaitan dengan urusan pangan dilakukan oleh perempuan mulai dari pengadaan bahan pangan sampai dengan menjadi hidangan untuk keluarga. Ketika pendapatan suami berkurang, maka istri atau ibu yang harus cerdas dalam mengatur keuangan rumahtangga terkait dengan pengeluaran pangan. Strategi mereka antara lain dengan cara memanfaatkan hasil pertanian dan peternakan disekitarnya mereka. Hal ini menjadi jaminan dalam ketersediaan pangan di dalam rumahtangga.

\section{KESIMPULAN}

Pada aktivitas pertanian, laki-laki berperan dalam pekerjaan berat. Sedangkan perempuan berperan pada pekerjaan yang dianggap ringan. Pola ini merujuk pada kebiasaan yang sudah menjadi budaya turun temurun masyarakat. Sejak kecil mereka telah melihat bagaimana orang tua membagi peran di dalam keluarga, sehingga hal ini juga menjadi acuan atau landasan mereka dalam membagi peran antara laki-laki dan perempuan di dalam aktivitas pertanian. Perempuan tani Gampong Blang Pala memisahkan beras/padi yang akan disimpan dirumah untuk kehidupan sehari-hari dan sebagian yang untuk dijual. Petani perempuan Gampong Blang Pala juga harus menyisihkan uang hasil penjualan untuk modal turun kesawah kembali dan uang untuk kebutuhan hidup lainnya. Hal ini menegaskan bahwa mereka sangat 
berperan dalam ketersediaan pangan rumahtangganya.

\section{DAFTAR PUSTAKA}

Holy, L. 1996. Anthropological Perspectives on Kinship. London and MI, USA: Pluto Press. Irianto, Sulistyowati (ed.). 2006. Perempuan dan Hukum: Menuju Hukum yang Berperspektif Kesetaraan dan Keadilan. Jakarta: Yayasan Obor Indonesia.

Novia, D. 2015. "Marginalisasi Perempuan dalam Pembangunan Pertanian". Prosiding Seminar Interdisiplin Ilmu Pendidikan Bagi Anak Perempuan, Pemberdayaan Perempuan dan Perubahan Sosial dan Lingkungan. Program Magister Kajian Perempuan, Program
Pasca Sarjana, Universitas Brawijaya, Malang.

Shamadiyah, N., Praza, R., \& Martina. (2018). The Role of Fishing Techniques with Tuah Teng on Food Security in Facing the Asean Economic Community. In Proceedings of MICoMS 2017 (pp. 175-180). Emerald Publishing Limited.

Sajogyo, P. (1994). Peranan Wanita Dalam Perkembangan Ekonomi. Obor. Jakarta.

Spradley, J.P. 2007. Metode Etnografi. Terj. M. Zulfa Elizabeth. Yogyakarta: Tiara Wacana. Tsing, Anna L. 1998. Di Bawah Bayang-Bayang Ratu Intan. Jakarta: Yayasan Obor Indonesia. 